\title{
Analisis Kebutuhan Kebijakan Pemerintah Kabupaten dalam Mengimplementasikan Keputusan Mahkamah Konstitusi No. 35/PUU-X/2012
}

\author{
Andi Massoeang Abdillah ${ }^{1^{*}}$, Yusran Jusuf2, M. Asar Said Mahbub² \\ ${ }^{1}$ Mahasiswa, Laboratorium Kebijakan dan Kewirausahaan, Fakultas Kehutanan, \\ Universitas Hasanuddin, Makassar \\ 2Staf Pengajar, Fakultas Kehutanan, Universitas Hasanuddin, Makassar \\ *Email: andimassoeang@yahoo.com
}

\begin{abstract}
This study aims to : (1)To identify Kajang eligibilities of customary law, based on the law 41 of 1999 (article 67) to be recognized by local authorities as before customaty law determination as indigenous forests. (2)To identify the obstacles in the process of a strengthening the community of Kajang customary law in Bulukumba regency.(3)To formulate policy needed in maintaining the existence of indigenous community and forest conservation. This study was conducted in the village of Tana Toa, Subdistrict of Kajang, Bulukumba, South Sulawesi province. Descriptive analysis was used to determine the condition of Kajang customary law, in accordance with the terms used to confirm customary law communities by the local governments, obstacles in the process of strengthening the customary law community, as well as to describe perceptions of stakeholders in relation with constitutional courts decisions. Policy analysis was used to form policies needed in maintaining the existence of indigenous communities and forest conservation. The results of the study showed that Kajang customary law qualified and has been confirmed as customary law communities. The form of policies needed were policies that could synergize government and customary law in managing and conserving forests, proportional policies and necessary technical policies that could regulate the management and procurement of forest resources by Kajang customary law community. The perception of stakeholders were varied, but all supporting the indigenous forests to be passed through local legislation. On the other hand the stakeholders expected the government could assist in the process and remain as a driver and controller of customary law communities in the management of forest resources.
\end{abstract}

Keywords: Decision of the Constitutional Court, Kajang Customary Law

\section{PENDAHULUAN}

Hutan di Indonesia terbagi dua berdasarkan Undang-undang No.41 Tahun 1999 yaitu hutan negara dan hutan hak. Selanjutnya dalam undang-undang tersebut dijelaskan bahwa hutan negara adalah hutan yang berada pada tanah yang tidak dibebani hak atas tanah. Sedangkan hutan hak adalah hutan yang berada pada tanah yang dibebani hak atas tanah. Undang-undang No. 41 Tahun 1999 Pasal 1, Ayat 6 menyebutkan bahwa Hutan adat adalah hutan negara yang berada dalam wilayah masyarakat hukum Adat. Jadi hutan adat atau hutan ulayat atau hutan marga atau hutan pertuanan atau sebutan lainnya merupakan milik masyarakat hukum adat dan termasuk dalam hutan negara berdasarkan penjelasan Pasal 1 Ayat 6 dalam Undang-undang No.41 Tahun 1999.

Putusan Mahkamah Konstitusi No. 35/PUU-X/2012 berisi beberapa pokok antara lain: Pertama, undang-undang kehutanan yang selama ini memasukan hutan adat sebagai bagian dari hutan negara merupakan bentuk dari pengabaian terhadap hak-hak masyarakat adat dan merupakan pelanggaran 
konstitusi. Kedua, hutan adat dikeluarkan posisinya dari sebelumnya merupakan bagian dari hutan negara kemudian dimasukan sebagai bagian dari kategori hutan hak. Ketiga, pemegang hak atas tanah adalah pemegang hak atas hutan. Keempat, otoritas negara terhadap hutan negara dan hutan adat berbeda-beda. Kelima, hal pokok lainnya adalah penegasan bahwa masyarakat adat merupakan penyandang hak (Arizona Y, 2013).

Putusan Mahkamah Konstitusi tersebut berimplikasi terhadap berubahnya status hutan adat menjadi hutan hak. Masyarakat adat akan semakin mudah untuk menerapkan kearifan lokal yang dimiliki guna menjaga kelestarian hutan dan mensejahterakan masyarakatnya. Namun demikian, dibutuhkan regulasi atau kebijakan dari pemerintah kabupaten untuk memperkuat aturan-aturan yang dimiliki oleh masyarakat adat dalam melakukan pengelolaan hutan, sehingga sinergi antara aturan adat dan aturan pngelolaan hutan pemerintah kabupaten dapat semakin harmonis dan tidak merugikan pihak lainnya.

Sulawesi selatan adalah salah satu provinsi yang memiliki banyak komunitas yang eksis sebagai masyarakat adat, seperti komunitas adat toraja, komunitas adat dan komunitas adat masamba. Kabupaten Bulukumba adalah salah satu daerah yang memiliki kawasan hutan yang didalamnya terdapat masyarakat adat. Berdasarkan TGHK (Tata Guna Hutan Kesepakatan) kawasan hutan yang berada di Kecamatan Kajang tersebut berfungsi sebagai hutan produksi dan memiliki luas 331,17 Ha.(Razak S, 2014). Secara factual eksistensi hutan adat yang berada di Kecamatan Kajang diakui oleh banyak kalangan, namun secara yuridis belum sah sebagai hutan adat dan keberadaan masyarakat hukum adatnya juga belum diakui secara sah oleh pemerintah daerah.

Penetapan hutan adat oleh pemerintah kabupaten melalui peraturan daerah tentunya harus melalui beberapa tahapan, salah satunya yaitu dengan melakukan pengukuhan masyarakat hukum adat terlebih dahulu dan selanjutnya dilakukan penetapan hutan adat melalui peraturan daerah. Pengukuhan masyarakat hukum adat berdasarkan undang-undang No.41 tahun 1999 pasal 67 harus memenuhi beberapa syarat untuk dapat ditetapkan sebagai masyarakat hukum adat.

Perubahan status hutan adat sebagai hutan Negara berdasarkan Undang-undang No.41 Tahun 1999 menjadi hutan adat berdasarkan Keputusan Mahkamah Konstitusi No. 35/PUU-X/2012 akan berpotensi memberikan dampak terhadap pengelolaan hutan adat. Oleh karena itu, dibutuhkan kebijakan yang bisa mensinergikan antara aturan adat dan aturan pengelolaan hutan oleh Pemerintah Kabupaten serta dibutuhkan penelitian dalam melihat keberadaan masyarakat hukum adat kajang berdasarkan undang-undang No.41 tahun 1999 pasal 67. Selain itu dibutuhkan persepsi stekholder yang terkait guna melihat respon dan tanggapan. Persepsi stekholder sangat dibutuhkan karena akan sangat bermanfaat bagi penelitian untuk mengidentifikasi dan menganalisis kebutuhan serta kepedulian berbagai pemangku kepentingan yang berkaitan langsung dengan adanya putusan Mahkamah Konstitusi No. 35/PUU-X/2012.

\section{METODE PENELITIAN}

\subsection{Waktu dan Tempat}

Penelitian ini dilaksanakan selama tiga bulan yaitu pada bulan Desember 2014 hingga bulan Februari 2015. Lokasi penelitian bertempat di Desa Tana Toa Kecamatan Kajang, Kabupaten Bulukumba Provinsi Sulawesi Selatan dengan objek penelitian adalah masyarakat adat Kajang.

\subsection{Teknik Pengambilan Data}

Data diperoleh melalui observasi lapang dilapangan dan wawancara langsung dengan berbagai pihak (masyarakat adat, tokoh adat kajang, dan akademisi). Selain melakukan wawancara, metode lain yang digunakan untuk mendapatkan informasi yaitu melalui Focus Grup Discussion (FGD) dengan pihak 
Pemerintah Daerah Bulukumba untuk mengetahui hambatan-hambatan dalam proses pengukuhan masyarakat hukum adat Kajang, Lima persyaratan pengukuhan masyarakat hukum adat yaitu masyarakat masih dalam bentuk paguyuban, ada kelembagaan, ada wilayah hukum adat yang jelas, ada pranata dan perangkat hukum.khususnya peradilan adat yang masih diataati, serta masih mengadakan pemungutan hasil hutan untuk pemenuhan kebutuhan sehari-hari.

Data lain diperoleh dari literature berupa data penelitian yang pernah ada sebelumnya sebagai bahan perbandingan dengan data yang didapatkan dilapangan nantinya, instansi terkait berupa peta wilayah dan berbagai data yang mendukung penelitian ini, dan laporan dari berbagai pihak yang berkaitan dengan penelitian ini. Data sekunder dikumpulkan meliputi putusan mahkamah konstitusi yang mengeluarkan hutan adat dari hutan Negara, data potensi daerah, keadaan umum lokasi serta data dan berbagai aturan-aturan adat yang pernah dicatat oleh pemerintah dalam hal ini dinas kehutanan.

\subsection{Metode Analisis Data}

Data yang terkumpul dalam penelitian ini selanjutnya diolah dan ditabulasi serta diklasifikasikan sesuai dengan tujuan dari penelitian ini. Data tersebut kemudian dianalisis secara deskriptif untuk mengetahui kondisi masyarakat adat Kajang, memenuhi syarat atau belum untuk dikukuhkan sebagai masyarakat hukum adat oleh pemerintah daerah, hambatan dalam proses pengukuhan masyarakat hukum adat, serta mendeskripsikan berbagai persepsi stekholder terkait putusan mahkamah konstitusi sehingga dapat dijelaskan berbagai solusi dan alternative yang dapat diberikan dikemudian hari.

Analisis kebijakan digunakan untuk merumuskan bentuk atau model kebijakan yang dibutuhkan untuk menjaga eksistensi komunitas adat dan kelestarian hutan.

Dunn membedakan tiga bentuk utama analisis kebijakan public salah satunya yaitu analisis Kebijakan Prospektif yang berupa produksi dan transformasi informasi sebelum aksi kebijakan dimulai dan diimplementasikan. Analisis kebijakan disini merupakan suatu alat untuk mensintesakan informasi untuk dipakai dalam merumuskan alternatif dan preferensi kebijakan yang dinyatakan secara komparatif, diramalkan dalam bahasa kuantitatif dan kualitatif sebagai landasan atau penuntun dalam pengambilan keputusan kebijakan. Ada beberapa pertanyaan yang harus dipenuhi untuk menganalsis kebutuhan kebijakan yaitu :

Tabel 1. Pertanyaan Analisis Kebutuhan Kebijakan

\begin{tabular}{|l|l|}
\hline 1 & Siapa yang membutuhkan kebijakan itu ? \\
\hline 2 & Mengapa analisis kebutuhan kebijakan itu dibutuhkan ? \\
\hline 3 & Meliputi apa saja analisis kebutuhan kebijakan itu? \\
\hline 4 & Untuk siapa kebutuhan itu dirumuskan dan bagaimana tingkat kegentingannya ? \\
\hline 5 & Bagaimana jenis dan jumlah data dikumpulkan untuk mencapai tujuan yang dirumuskan ? \\
\hline 6 & Bagaimana menentukan metode dan sumber yang digunakan dalam mengumpulkan data ? \\
\hline 7 & Kendala-kendala apa yang dihadapi dalam mengumpulkan data? \\
\hline
\end{tabular}

\section{HASIL DAN PEMBAHASAN}

\subsection{Syarat Pengakuan Menjadi Masyarakat Hukum Adat}

Masyarakat hukum adat kajang sudah memenuhi syarat untuk diakui pemerintah daerah Bulukumba sebagai masyarakat hukum adat. berdasarkan undang-undang No.41 tahun 1999 pasal 67 ada lima syarat yang harus dipenuhi sehingga masyarakat hukum adat dapat dikukuhkan oleh pemerintah daerah. Syaratsyarat tersebut sebagai berikut : 


\section{a. Masyarakatnya Masih dalam Bentuk Paguyuban (Rechtsgemeenschap)}

Paguyuban merupakan kelompok sosial yang anggota-anggotanya memiliki ikatan batin yang murni, bersifat alamiah, dan kekal. Masyarakat adat kajang masih dalam bentuk paguyuban atau komunitas karena sesuai kenyataan dan berdasarkan hasil penelusuran masyarakat adat kajang memiliki ikatan batin yang murni dan alamiah serta kekal. Hal tersebut ditunjukkan dengan kesatuan masyarakat hukum adat memiliki bentuk dan ciri khas khusus yang membedakannnya dengan kelompok/komunitas warga pada umumnya.

Masyarakat hukum adat kajang dikatakan masih berbentuk komunitas karena pada kenyataannya memiliki kelembagaan dan memiliki ciri khas tersendiri dalam mengatur dan mengelola hutannya, selain itu Masyarakat Adat Kajang juga memiliki ciri khas dan cara berbeda dalam urusan hubungan sosial, hukum kemasyarakatan, adat istiadat, bahasa, budaya, pemilikan tanah dan sumber daya alam. Dalam kesatuan masyarakat hukum adat bentuk dan sistem yang mereka gunakan lebih bersifat komunal dan sangat patuh dengan norma dan nilai yang telah mereka terima secara turun menurun. Selain itu Masyarakat Hukum Adat Ammatoa Kajang yang telah lama hidup dalam suatu ikatan kesatuan masyarakat hukum bahkan secara mitologi dipercayai telah hadir sejak ribuan tahun lalu dan sampai saat ini eksistensinya tetap nyata dan diakui keberadaannya oleh berbagai pihak.

Masyarakat hukum adat kajang sudah memenuhi satu syarat yang pertama berdasarkan Undangundang nomor 41 tahun 1999 pasal 67 dalam penjelasannya yang mengatakan bahwa salah satu syarat pengukuhan masyarakat hukum adat yaitu masyarakatnya masih dalam bentuk paguyuban atau bahasa lainnya dalam bentuk komunal atau komunitas.

\section{b. Kelembagaan dalam Bentuk Perangkat Penguasa Adat}

Masyarakat hukum adat kajang memiliki kelembagaan yang ditunjukkan dengan adanya struktur kelembagaan sebagai berikut :

Tabel 2. Kelembagaan Masyarakat Adat Kajang

\begin{tabular}{|l|l|}
\hline 1 & Ammatoa; \\
\hline 2 & Anrongta ri Pangi' dan Anrongta Bongkina; \\
\hline 3 & $\begin{array}{l}\text { Ada' lima ri Tanakekea, terdiri dari: Galla Pantama, Galla Lombo', Galla Malleleng, Galla Kajang, } \\
\text { dan Galla Puto; }\end{array}$ \\
\hline 4 & $\begin{array}{l}\text { Ada' lima ri Tanalohea, terdiri dari: Galla Ganta', Galla Sangkala, Galla Sapa', Galla Bantalang } \\
\text { dan Galla Anjuru'; }\end{array}$ \\
\hline 5 & Karaeng Tallua, terdiri dari:Labbiria, Sulehatang dan Ana' Karaeng Tambangan/ Moncongbuloa; \\
\hline 6 & Tutoa Sangkala; \\
\hline 7 & Tutoa Ganta; \\
\hline
\end{tabular}

Masyarakat hukum adat kajang sudah memenuhi salah satu syarat berdasarkan Undang-undang nomor 41 tahun 1999 yang terdapat pada pasal 67 dalam penjelasannya yang mengatakan bahwa salah satu syarat pengukuhan masyarakat hukum adat yaitu masyarakatnya memiliki kelembagaan dalam bentuk perangkat penguasa adatnya.

c. Wilayah Hukum Adat yang Jelas

Wilayah adat Masyarakat Hukum Adat Ammatoa Kajang terdiri dari wilayah Ilalang Embayya atau Rambang Seppang dan Ipantarang Embayya atau Rambang Luara. Ilalang Embayya atau Rambang Seppang merupakan wilayah adat dimana Pasang dilaksanakan dalam seluruh sendi-sendi kehidupan. 
Batas-batas wilayah adat Kajang tersebut terletak disebelah barat Desa Tana Toa, Batu Lohe dan Desa Sampeang (Kec. Rilau Ale), sebelah timur ibu kota Kecamatan Kajang (Kassi-wilayah pesisir pantai), sebelah selatan Desa Jo'jolo (Kec. Bulukumpa), Desa Bonto Biareng (Kec. Kajang), Desa Bonto Mangiring (Kec. Bulukumpa), Desa Tammatto (Kec. Ujungloe) dan Desa Palangisang (Kec. Ujungloe, batas-batas wilayah pertanian, perladangan serta hutan adat yang dihuni oleh komunitas adat Kajang dan sekarang masuk areal HG PT.PP Lonsum), dan sebelah Utara menunjukkan batas-batas kawasan hutan adat yang memanjang disekitar perbatasan Kabupaten Bulukumba dan Kabupaten Sinjai.

Secara administratif pemerintahan kecamatan, batas wilayah adat Ammatoa Kajang sekarang berada di tiga wilayah administratif pemerintahan kecamatan, yaitu: Kajang (desa Tana Toa dan ibu kota kecamatan Kajang/Kajang kassi, dan desa Bonto Biraeng), Bulukumpa (desa Jo'jolo, desa Bonto Mangiring), dan Ujung Loe (Desa Tammato, Desa Palangisang). Seluruh warga masyarakat yang bermukim di dalamnya. Ipantarang Embayya atau Rambang Luara merupakan wilayah adat, sebagian besar warga masyarakat yang bermukim di wilayah ini tidak secara utuh melaksanakan Pasang.

Peta yang dipetakan oleh Balang dan Dinas Kehutanan Kabupaten Bulukumba yang menjelaskan wilayah adat masyarakat hukum adat kajang yang masih belum bersifat final karena masih adanya permasalahan yang terjadi pada penetapan wilayah adat masyarakat hukum adat kajang, akan tetapi yang ingin disampaikan oleh peta tersebut menunjukkan bahwa wilayah hukum adat masyarakat hukum adat kajang di klasifikasikan menjadi dua yaitu wilayah adat kajang dalam dan wilayah adat kajang yang berada diluar walaupun hal tersebut sebenarnya masih menjadi perbincangan karena masih adanya yang mempetanyakan terkait batasan sebenarnya dari wilayah hukum adat masyarakat hukum adat Kajang.

\section{d. Pranata dan Perangkat Hukum, Khususnya Peradilan Adat, yang Masih Ditaati}

Pengertian pranata sosial secara prinsipil tidak jauh berbeda dengan apa yang sering dikenal dengan lembaga sosial, organisasi sosial maupun lembaga kemasyarakatan, karena di dalam masing-masing istilah tersebut terisrat adanya unsur-unsur yang mengatur setiap perilaku warga masyarakat.

Soekanto (2004) menjelaskan bahwa lembaga kemasyarakatan (Pranata Sosial) adalah himpunan norma-norma dari segala tindakan yang berkisar pada suatu kebutuhan pokok di dalam kehidupan masyarakat

Masyarakat hukum adat kajang memiliki pranata dan perangkat hukum yang masih ditaati terutama dalam peradilan adatnya. Pasang ri kajang merupakan pranata dan perangkat hukum masyarakat adat kajang yang masih ditaati dan masih sering dilakukan saat terjadi masalah yang berkaitan dengan adat.

Pranata merupakan aturan secara khusus yang merupakan alat kelengkapan perangkat hukum. Dalam komunitas adat kajang pranata dapat berupa upacara adat serta aturan yang tidak tertulis yang merupakan pasang.

Menurut Katu (2005) pasang ri kajang adalah ungkapan bahasa konjo, semacam bahasa daerah yang cenderung diidentifikasikan sebagai bahasa Proto-Makassar1 dan bahasa ini dipakai sebagai alat komunikasi oleh penduduk kecamatan Kajang dan sekitarnya. Pasang dapat berarti nasehat atau wasiat. Dapat pula berarti tuntunan atau amanah dan juga dapat bermakna renungan atau ramalan/ selain itu dapat pula berarti peringatan atau mengingat. Begitulah antara lain pengertian-pengertian tentang pasang ri kajang. Seluruh isi dan makna pasang tersebut itu diwariskan secara turun temurun dari satu generasi ke generasi berikutnya melalui penuturan lisan atau oral dengan bentuk ungkapan-ungkapan atau cerita-cerita lisan.

Hal tersebutlah yang membuat pasang harus dipatuhi dan dijalankan karena merupakan pedoman bagi masyarakat adat kajang dalam bertindak. Menurut Akib (2003) menjelaskan bahwa pasang yang memuat nilai-nilai "kunne" yakni pedoman dalam makna komunitas yang berpedoman dalam menghadapi kehidupan keduniaan, tetapi dengan inti atau tujuan utama untuk "konjo mange" (suatu kehidupan yang diharapkan akan serba berkecukupan atau koasa'). Adanya system kepercayaan yang nilai ajarannya berasal dari pasang 
menyebabkan komunitas senantiasa berpegang pada aturan-aturan Tu Tie' A,ra'na termasuk keharusan berkamase-masea dalam melaksanakan aturan-aturan tersebut.

Selain pasang yang merupakan pranata atau alat keelengkapan hukum yang dimiliki oleh komunitas adat kajang juga terdapat upacara-upacara adat yang menjadi tradisi masyarakat adat kajang.

Menurut Mahbub (2013) dalam desertasinya yang berjudul Dialektika pengetahuan local dan non local merangkum setidaknya terdapat delapan belas jenis upacara adat yaitu:

Tabel 3. Upacara Masyarakat Adat Kajang

1. Upacara A'tompolo, sebagai rasa syukur atas kelahiran seorang bayi.

2. Upacara Akkalomba, merupakan upacara memohon keselamatan

3. Upacara Akkatere, upacara ini mirip dengan acara pemotongan rambut bagi anak bayi yang baru dilahirkan

4. Upacara Passalang, yaitu upacara khitanan

5. Upacara Pa'buntingan atau upacara pesta perkawinan.

Pranata Sosial diatas berupa pasang dan upacara-upacara yang diajalankan dan ditaati oleh komunitas masyarakat adat kajang, merupakan suatu pranata yang berfungsi untuk mengatur agar kebutuhan hidup manusia dapat terpenuhi secara memadahi, juga sekaligus untuk mengatur agar kehidupan sosial warga masyarakat bisa berjalan dengan tertib dan lancar sesuai dengan kaidah-kaidah yang berlaku pada komunitas masyarakat adat Kajang.

\section{e. Pemungutan Hasil Hutan Di Wilayah Hutan Sekitarnya untuk Pemenuhan Kebutuhan Sehari-Hari}

Masyarakat masih mengadakan pemungutan hasil hutan berupa buah-buahan, rotan,kayu dan lebah madu pada waktu tertentu jika ada ritual adat, selain itu masyarakat adat juga melakukan kegiatan bercocok tanam seperti jagung sehingga dapat digunakan dalam kehidupan sehari-hari. Itu dikarenakan dalam wilayah adat kajang ada sebuah wilayah yang diperbolehkan untuk melakukan aktivitas pertanian sehingga hasil dari kegiatannya tersebut dapat digunakan untuk pemenuhan hidup sehari-harinya.Akan tetapi Wilayah tersebut, bukan wilayah yang bisa digunakan oleh umum, lahan tersebut disebut Kabibing, yang hanya bisa digunakan oleh keluarga Ammatoa saja, bukan untuk areal public yang dapat dimanfaatkan oleh orang pada umumnya.

\subsection{Hambatan dalam Proses Pengukuhan Masyarakat Hukum Adat Kajang Kabupaten Bulukumba}

Adapun Hambatan yang dihadapi dalam proses pengukuhan masyarakat hukum adat kajang berdasarkan hasil wawancara yang dilakukan kepada kepala Bagian Hukum Kabupaten Bulukumba yaitu penetapan wilayah adat. Penetapan wilayah tersebut terhambat dikarenakan adanya wilayah adat kajang yang dikuasai oleh pihak Lonsum berdasarkan hasil kajian pemerintah Kabupaten Bulukumba bekerja sama dengan Balang. Sementara itu pihak lonsum memiliki landasan hukum yang kuat atas penguasaan tanah yang diklaim sebagai wilayah adat kajang yaitu dibuktikan dengan adanya HGU (Hak Guna Usaha).

Hal tersebut menjadi hambatan karena syarat wilayah hukum adat dalam proses pengukuhan masyarakat hukum adat dianggap oleh Aliansi Masyrakat Adat Nusantara dalam diskusi-diskusi yang dilakukan mengharuskan disebutkannya dalam peraturan daerah wilayah adat yang jelas sehingga hal tersebutlah yang menjadi salah satu hambatan yang ditemukan oleh peneliti dilapangan. 
Pada Masa lampau seluruh lahan di wilayah Masyarakat hukum adat Kajang merupakan lahan milik bersama yang didayagunakan sesuai dengan aturan adat untuk kepentingan bersama. Informasi tersebut diperoleh melalui wawancara dengan tokoh masyarakat adat Kajang Mansyur Embas yang menjelaskan terkait wilayah adat kajang. Selain itu informasi juga diperoleh dari polisi kehutanan yang juga tokoh masyarakat kajang yang bernama Jumarling yang menjelaskan banyak hal terkait permasalahanpermasalahan sengketa lahan yang terjadi di wilayah adat kajang. Di sebagian besar lokasi sistem tenurial tersebut telah berubah menjadi tanah milik pribadi (private property) dan tanah negara (state proverty) dengan status kawasan hutan negara dan areal pemanfaatan lain yang dikonsesikan kepada perusahaan (HGU). Informasi yang didapatkan adanya kasus pada lahan lonsum yang seharusnya sesuai ijin hanya seluas 5800 ha sedangkan yang dikuasai mencapai 20.000 ha.

Masalah tersebut ada kaitannya dengan lembaga adat Moncong Buloa berkeluarga yang terdiri dari kepala desa Tambangan, bonto biraeng, tana toa, lembanna dan bonto rannu yang terjadi pada tahun 1970 sampai dengan tahun 1990-an. Lembaga adat moncong buloa tersebut bekerja sama dengan pihak PT. Lonsum untuk dipinjam tanahnya dan hasilnya untuk dibagi dua. Kemudian pada saat itu masyarakat dipaksa untuk menyerahkan tanahnya. Akhirnya moncong buloa bekerja sama dengan Karaeng Makki sebagai tokoh masyarakat untuk sama-sama dengan pihak PT. Lonsum untuk mengambil dan mengelola hutan.

Kebijakan negara dibidang pertanahan, kehutanan berpengaruh besar terhadap perubahan sistem tenurial lokal. Dalam sistem tenurial lokal, fungsi sosial dan lingkungan dari lahan lebih diutamakan dibanding fungsi ekonominya. Hak warga terbatas dalam pemanfaatan dan pengelolaannya. Sistem tenurial lokal tersebut telah mengalami disorientasi karena program sertifikasi lahan dan penerbitan HGU. Tanah-tanah milik bersama Masyarakat hukum adat Kajang dikuasai dan dimiliki oleh individu-individu melalui proses sertifikasi tanah. Lebih dari 7000 ha tanah di wilayah adat Kajang juga telah berubah statusnya dari tanah milik bersama menjadi tanah negara yang dikonsesikan kepada perusahaan. Informasi tersebut didapatkan dari hasil wawancara yang dilakukan kepada salah seorang polisi kehutanan yang bertugas di Desa Tana Toa yang bernama Jumarling. Demikian pula halnya dengan penunjukan kawasan hutan di wilayah adat menjadi kawasan hutan milik negara.

\subsection{Bentuk Kebijakan yang Dibutuhkan untuk Menjaga Eksistensi Komunitas Adat dan Kelestarian Hutan}

Putusan mahkamah konstitusi No. 35 mendasarkan pada tuntutan Aliansi Masyarakat Adat Nusantara akibat dibeberapa daerah terjadi konflik antara pemerintah dan masyarakat adatnya (Arizona $Y, 2013$ ), sedangkan fakta yang terjadi di Kajang menunjukkan bahwa hubungan antara pemerintah dan masyrakat adat kajang sangatlah harmonis, bahkan menurut pemimpin tertinggi masyarakat adat kajang yaitu Ammatoa mengatakan bahwa adat dan pemerintah haruslah bekerja sama dalam melestarikan hutan. Ammatoa memberikan pasang yang berbunyi :

"Punna nanro tana lanibicara, jarungi ada' bannang panjahi'l pamarintayya "

"Punna aturang lanibicara, jarungi pamarintayya na bannang panjahi'l ada"

Pasang diatas menjelaskan bahwa antara pemerintah dan adat tidak dapat dipisahkan karena masing-masing memiliki peran yang besar dalam menjaga dan melestarikan hutan di Kajang. Pasang tersebut mengibaratkan jarum dan benang yang ketika ingin menyelesaikan suatu masalah maka pemerintah dan adat harus ada karena kedua unsur tersebut tidak dapat dipisahkan.

Analisis kebijakan ini dibutuhkan karena permasalahan yang terjadi di Kajang berbeda dengan permasalahan yang terjadi di daerah lainnya dan sangat berbeda permasalahan yang menjadi dasar dikabulkannya permohonan Aliansi Masyarakat Adat Nusantara. Sehingga analisis kebijakan ini diperlukan untuk melihat kemungkinan-kemungkinan yang akan terjadi dikemudian hari baik dalam hal positif ataupun dalam sisi negative dengan adanya putusan mahkamah konstitusi ini.

Dampak yang timbul akibat adanya putusan Mahkamah Konstitusi tersebut berpotensi menimbulkan kekacauan. Kekacauan dimaksudkan yaitu semakin kacaunya hubungan antara pemerintah dan komunitas 
masyarakat hukum adat yang selama ini terjalin dengan baik dan harmonis maka akan semakin mengacaukan kondisi yang ada saat ini. Putusan mahkamah konstitusi tersebut masih bersifat sangat umum dan pastinya putusan mahkamah konstitusi tersebut tetap harus dijalankan dan dipatuhi dengan syarat adanya petunjuk tekhnis dan aturan yang lebih khusus yang berkaitan dengan administrasi ataupun kelembagaan masyarakat hukum adat kajang. Petunjuk tekhnis tersebut dapat berupa peraturan bupati ataupun peraturan ditingkat kepala dinas. Peraturan bupati tersebut yang akan dikeluarkan nantinya setidaknya mengatur hal-hal yang berkaitan dengan administrasi, kelembagaan, tata cara, larangan-larangan, pengertian, ruang lingkup serta sanksi yang diberikan jika adanya suatu pelanggaran dalam pengelolaan hutan adat. Pemerintah yang memiliki peran sebagai fungsi pemberdayaan diharapkan dapat melakukan penguatan masyarakat dan penguatan kelembagaan agar masyarakat dapat mandiri dalam melakukan pengelolaan hutan tapi tidak terlepas dari pengawasan pemerintah. Yang perlu dipikirkan saat ini yaitu hal-hal yang dibutuhkan dalam melakukan penguatan individual dan institusional dalam komunitas masyarakat adat kajang.

Analisis kebijakan yang dilakukan meliputi pemerintah dan masyarakat adat yang nantinya akan merasakan kebijakan yang diterapkan nantinya. Pemerintah ini berperan sebagai actor pembuat kebijakan bersama masyarakat yang juga berperan sebagai pengontrol kebijakan nantinya. Masyarakat sebagai objek yang dikenai kebijakan dan juga turut berperan dalam pembuatan kebijakan karena kebijakan yang dibuat nantinya haruslah sesuai kebutuhan masyarakat dan demi kepentingan masyarakat hukum adat kajang. Bentuk kebijakan yang dibutuhkan secara garis besar yaitu:

\section{a. Dibutuhkan Kebijakan Teknis untuk Mengatur Pengelolaan Hutan dalam Wilayah Hukum Adat}

Keseluruhan bentuk kebijakan yang dibutuhkan berupa kebijakan tekhnis, kebijakan kekhususan serta kebijakan yang dapat mensinergikan antara pemerintah dan masyarakat hukum adat kajang. Kebijakan tekhnis yang dimaksudkan yaitu suatu aturan yang dapat menjadi pedoman dalam melakukan pengelolaan hutan, baik itu dalam hal ruang lingkup, administrasi, kelembagaan, tata cara, larangan serta sanksi-sanksi. Kebijakan tekhnis yang akan dikeluarkan nantinya dapat berupa peraturan bupati ataupun aturan ditingkat kepala dinas.

b. Dibutuhkan Kebijakan atau Aturan yang Proporsional atau Kekhususan pada Tiap Komunitas Masyarakat Hukum Adat dalam Hal Pengelolaan Sumberdaya Hutannya

Kebijakan kekhususan atau proporsional diharapkan mampu mengatur dengan baik pengelolaan hutan adat yang ada di Kajang. Kebijakan proporsional berkaitan dengan mekanisme pengelolaan yang dimulai dari proses pemilikan, serta perencanaan pengelolaan hutan adat kedepannya. Kebijakan yang proporsional ini dibutuhkan karena karena aturan atau kebijakan yang dikeluarkan tidak melanggar hukum, bisa diterima secara social, serta dapat diimplementasikan secara tekhnis. Maka dari itu putusan mahkamah konstitusi yang masih bersifat umum haruslah diikuti dengan kebijakan yang secara khusus mengatur dan menjadi pedoman bagi tiap-tiap komunitas masyarakat hukum adat utamanya komunitas masyarakat hukum adat yang ada di Kajang karena permasalahan ditiap komunitas adat tersebut berbeda-beda sehingga aturan yang harus dikeluarkan taua yang harus dibuat harus sesuai dengan kebutuhan masing-masing komunitas adat sehingga cita0cita mewujudkan kelestarian hutan dapat dicapai kemudian hari.

c. Dibutuhkan Kebijakan dari Pemerintah Daerah yang dapat Mensinergikan Antara Pemerintah dan Masyarakat Adat Kajang Sehingga Cita-Cita Bersama dalam Kelestariian Hutan dapat Terlaksana

Kebijakan atau aturan yang dimaksudkan pada poin ketiga diatas yaitu suatu kebijakan yang dapat mensinergikan antara pemerintah dan masyarakat hukum adat kajang. Hal yang perlu disenergikan adalah 
berupa aturan-aturan adat nantinya yang dapat diadopsi pemerintah untuk dijadikan sebagai aturan pengelolaan hutan. Hal tersebut dianggap perlu karena aturan-aturan adat yang dimiliki oleh masyarakat hukum adat kajang sangatlah banyak dan beragam, selain itu aturan adat yang mereka jalani sangatlah baik untuk diterapkan, buktinya hutan yang mereka tempati seluas 331,17 ha yang sebemarnya merupakan hutan produksi akan tetapi mereka tetap menjaganya dikarenakan aturan adat yang mereka jalani sangatlah kuat. Maka dari itu dengan nantinya adanya kebijakan tekhnis dan kebijakan kekhususan diharapkan pemerintah dapat mengadopsi aturan-aturan adat yang sesuai sehingga semakin mnguatkan aturan yang akan dibuat nantinya.

\subsection{Persepsi Stekholder}

Persepsi Stekholder kedepannya jika hutan adat kajang sudah resmi dikeluarkan dari hutan Negara sangatlah beragam, akan tetapi semuanya mendukung masyarakat hukum adat kajang untuk dikukuhkan oleh pemerintah kabupaten Bulukumba. Berikut berbagai persepsi stekholder terkait hutan adat kajang dari Dinas Kehutanan dan perkebunan Kabupaten Bulukumba yaitu Kekhawatiran dengan adanya putusan Mahkamah Konstitusi No.35 ini justru akan merusak tatanan yang sudah baik selama ini, masukan yang diberikan oleh Dinas Kehutanan dan Perkebunan Kabupaten Bulukumba yaitu putusan Mahkamah Konstitusi No. 35 tersebut tidak diberlakukan secara umum akan tetapi hanya berlaku pada kawasan hutan yang memiliki sengketa dengan masyarakat adat setempat. Sementara itu, pandangan dari Dinas Kebudayaan dan Pariwisata ialah dibutuhkan sebuah kebijakan atau kesepakatan dari seluruh pihak terkait untuk tetap bersama-sama menjaga dan melestarikan hutan, karena sangat disadari bahwa hutan adat kajang saat ini menjadi penyangga kehidupan bagi masyarakat disekitarnya. Pandangan yang lain juga diberikan oleh kepala bagian hukum yang mengatakan bahwa dengan penetapan hutan adat ini maka masayarakat akan semakin leluasa menjalankan kearifan lokal yang dimiliki. Untuk memperkuat berbagai persepsi stakeholder maka tokoh masyarakat adat juga memberikan pandangan yaitu Untuk semakin menguatkan masyarakat hukum adat Kajang tentunya dibutuhkan peraturan daerah untuk mengukuhkan komunitas masyarakat hukum adat dan dihimbau agar seluruh elemen masyarakat maupun pemerintah untuk terlibat dalam regulasi atau kebijakan yang akan dikeluarkan nantinya.

\section{Kesimpulan}

a. Masyarakat hukum adat kajang sudah memenuhi syarat berdasarkan undang-undang No.41 tahun 1999 pasal 67 untuk diakui sebagai masyarakat hukum adat.

b. Kendala dalam proses pengukuhan masyarakat hukum adat kajang kabupaten Bulukumba yaitu penetapan wilayah hukum adat Kajang.

c. Stekholder menyadari dibutuhkannya kesepakatan bersama antar semua pihak utamanya masyarakat hukum adat untuk terus menjaga dan melestarikan hutannya, disisi lain stekholder mengharapkan pemerintah tetap sebagai pengendali dan pengontrol masyarakat hukum adat dalam pengelolaan sumberdaya hutannya.

d. Bentuk kebijakan yang dibutuhkan yaitu dibutuhkan kebijakan yang dapat mensinergikan antara pemerintah dan adat dan dibutuhkan kebijakan yang proporsional sesuai dengan permasalahan yang terjadi serta dibutuhkan kebijakan tekhnis yang dapat mengatur pengelolaan dan pengusaan sumberdaya hutan oleh masyarakat hukum adat Kajang. 


\section{DAFTAR PUSTAKA}

Akib, Y. 2003. Potret Manusia Kajang. Makassar : Pustaka Refleksi.

Akib, Y. 2003. Ammatoa : Komunitas Berbaju Hitam. Makassar : Pustaka Refleksi.

Amsari, F, 2011. Perubahan UUD 1945: Perubahan konstitusi Negara Kesatuan Republik Indonesia melalui keputusan Mahkamah Konstitusi, Jakarta: Rajawali Press.

Arizona, Y. 2013. 'HUTAN ADAT BUKAN LAGI HUTAN NEGARA: Membumikan Putusan MK No. 35/PUUX/2012 dalam konteks pembaruan hukum daerah', Makalah disampaikan dalam Workshop Pengakuan dan Penguatan Pengelolaan Hutan Adat dan Kawasan Konservasi oleh Masyarakat Adat (ICCAs): Pengalaman dan Ruang Kebijakan., Malinau, 24-26 September2013http://www.academia.edu/4585452/Membumikan_Putusan_MK_35_dlm_Konteks_Pe mbaruan_Hukum_Daerah.

Arizona, Y. 2012. Konsepsi konstitusional penguasaan negara atas agraria dan pelaksanaannya, Tesis pada Program Magister Ilmu Hukum, Fakultas Hukum Universitas Indonesia.

Arizona, Y, S.Rakhma, M.Herwati dan G.Nagara, 2012. Anotasi Putusan MK No. 45/PUU-X/2011 mengenai pengujian konstitusional kawasan hutan dalam Pasal 1 angka 3 UU No. 41 Tahun 1999 tentang Kehutanan.

Badan Perencanaan Pembangunan Daerah (BAPPEDA) Kabupaten Bulukumba. 2011. Profil daerah Kabupaten Bulukumba. Bulukumba.

Departemen Kehutanan (Dephut). 1999. Undang-Undang No. 41 Tahun 1999 tentang Kehutanan. Jakarta Katu, MA. 2008. Kearifan Manusia Kajang. Makassar : Pustaka Refleksi.

Kementrian K. 2014. Peraturan Menteri Dalam Negeri nomor 52 tahun 2014 tentang Pedoman Pengakuan dan Perlindungan Masyarakat Hukum Adat. Jakarta.

Mahbub, A. 2013. Dialektika Pengetahuan Lokal dan Non Lokal (Studi Kasus Pasang Ri Kajang dalam Pengelolaan Hutan Adat Kajang) (Desertasi). Universitas Hasanuddin. Makassar.

Palammai, R.2012. Sejarah Eksistensi Ada' Lima Karaeng Tallua di Kajang. Bulukumba : Dinas Kebudayaan dan Pariwisata.

Razak, S. 2014. Pengakuan Masyarakat Adat Ammatoa Kajang Sulawesi Selatan dalam Dialog Nasional. Jakarta.

Soekanto, S. 2004, Sosiologi Suatu Pengantar. Jakarta: PT Raja Grafindo Persada. 